\title{
My Wooden House: Unit Cost of Popular Housing in Acre state, Brazil
}

\author{
Maria de Fátima de Brito Lima ${ }^{1}$ (D), Álvaro Nogueira de Souza² (D), \\ Paulo José Prudente de Fontes ${ }^{1}$ (D), Divino Eterno Teixeira ${ }^{1}$ (D), \\ Maísa Santos Joaquim ${ }^{2}$ \\ ${ }^{1}$ Serviço Florestal Brasileiro - SFB, Brasília/DF, Brasil \\ ${ }^{2}$ Universidade de Brasília - UnB, Brasília/DF, Brasil
}

\begin{abstract}
Housing deficit is a problem that affects low-income populations in Brazil, with over 6 million families affected nationwide and approximately 631 thousand in the North region of the country. Ordinance no. 318/2014 of the Brazilian Ministry of Cities authorized the construction of popular housing using timber as raw material in that region. The objective of this study was to establish the unit cost of a wooden dwelling, referenced in the project Popular Wooden Housing (PWH) developed by the Laboratory of Forest Products and the University of Brasília (UNB) for the National Rural Housing Program (NRHP). The Basic Unit Cost $\left(\mathrm{BUC} / \mathrm{m}^{2}\right)$ methodology was used, with collection of prices in Rio Branco, capital of the state of Acre, for composition of the Final Unit Cost $\left(\mathrm{FCU} / \mathrm{m}^{2}\right)$ of a wood construction. Mean cost of $\mathrm{R} \$ 934.52 / \mathrm{m}^{2}$ was observed from September 2015 to April 2016. Feasibility of wood construction was demonstrated by a final cost per $\mathrm{m}^{2} 28.06 \%$ lower than that of a conventional masonry house.
\end{abstract}

Keywords: NRHP Popular Wooden Housing, social housing, costs. 


\section{INTRODUCTION}

Right to housing, ensured by the Constitution of the Federative Republic of Brazil, is a fundamental element for the consolidation of public housing policies (Brasil, 1988). To meet this demand, the Government launched the Program Minha Casa, Minha Vida (PMCMV) in March 2009 with the purpose of reducing the housing deficit in the country, estimated in 6 million homes, and offering housing opportunities to low-income citizens. In the same year, the National Rural Housing Program (PNHR) was created and regulated within the PMCMV, aiming to assist 685 thousand families in the rural area (Brasil, 2016).

In 2012, representatives of the Extractive Communities of the North of Brazil requested PNHR managers with regard to the possibility of building their dwellings using wood as main raw material. In this context, in order to offer solutions to fill this gap and make the use of wood as construction material feasible within the scope of the PNHR, a group composed of representatives and technicians from several areas of the Government, researchers from the Forest Products Laboratory (LPF) - a research center of the Brazilian Forest Service (SFB) -, and professors from Brazilian universities was formed with the objective of discussing the theme (SFB; LPF, 2013).

The result of this discussion was the presentation of a technical proposal that culminated in the preparation and publication of Ordinance no. 318/2014 by the Brazilian Ministry of Cities addressing the use of wood in the construction and repair of dwellings within the PNHR/PMCMV. The technical proposal of this Work Group was based on the project Popular Wooden Housing (PWH) developed in 2002 by the LPF in partnership with the University of Brasília (UnB) (Melo et al., 2002; SFB; LPF, 2013; Brasil, 2014).

The conception of this project did not include costs, in spite of the construction of several housing units in the municipalities of Pimenta Bueno, Espigão do Oeste, and Pimenteiras in the state of Rondônia, Manacapuru in Amazonas state, and Paragominas in Pará state. These costs were not estimated because of the use of wood seized and donated by the Brazilian Institute of Environment and Renewable Natural Resources (IBAMA) and use of unpaid labor provided by the homeowners within the Solidary Community Program (Melo et al., 2002).
Therefore, the present study seeks to demonstrate the Final Unit Cost $\left(\mathrm{FUC} / \mathrm{m}^{2}\right)$ of a popular wooden house using as reference the methodology of Basic Unit Cost $\left(\mathrm{BUC} / \mathrm{m}^{2}\right)$ applied in the construction of conventional masonry popular houses and standardized by the Brazilian Association of Technical Standards (ABNT). Thus, the objective was to demonstrate that the costs of building popular wooden dwellings, especially in the North region of Brazil, meet the purposes of the PNHR, and are economically more attractive than those for construction of a similar masonry dwelling.

\section{MATERIAL AND METHODS}

\subsection{Characterization of the study area}

The state of Acre, located in the extreme west of Brazil, occupies an area of $164,123 \mathrm{~km}^{2}$, integrates the North region, and borders the states of Amazonas and Rondônia, Bolivia and Peru (IBGE, 2010).

According to the estimates of the Brazilian Institute of Geography and Statistics (IBGE), the state of Acre had 733,559 inhabitants, with 532,279 of them living in urban areas and 201,280 in rural areas in 2015. The general housing deficit was 29,939 households, with more than 17,000 in the state capital and rural areas. The average number of citizens per household was 3.82. The state capital, Rio Branco, is the largest and most populous city in the state, with a population estimated by the IBGE of 370,550 inhabitants in 2015 , and the sixth largest city in the North region of Brazil. It is $8835 \mathrm{~km}^{2}$ large, approximately $153 \mathrm{~m}$ above sea level, and distant $3105 \mathrm{~km}$ from Brasília (IBGE, 2015).

The choice of Acre state was due to the knowhow of the Technology Foundation of the State of Acre (FUNTAC) on the construction of popular wooden houses (FUNTAC, 2003); timber production in the region, which includes the municipalities of Rio Branco, Capixaba, Epitaciolândia, Sena Madureira, Senador Guiomard, and Xapuri, of approximately 193,000 m³/year (SFB; IMAZON, 2010); and a rural housing deficit that can be met within the scope of the PNHR.

\subsection{Data collection}

Based on the PWH project, the study development can be divided into three distinct stages, as described in Table 1. 
The timber companies that collaborated in the market price collection at the time processed the wood characterized by the LPF according to Table 2, as well as Cambará vermelha (Lantana camara L.) and Castanharana (Eschweilera atropetiolata S. A. Mori), all high-density, fungus-resistant hardwood of higher commercial value (Souza et al., 2014). These were the wood species considered in this study.

Cost estimation of the materials specified in the electric, hydraulic and sanitary projects was conducted through collection of market prices using the National System of Costs Survey and Indexes of Construction
(SINAPI) in the same months of the wood market price collection, that is, from September 2015 to April 2016.

\subsection{Composition of the Final Unit Cost $\left(\mathrm{FUC} / \mathrm{m}^{2}\right)$ for popular wooden housing based on the Basic Unit Cost $\left(B U C / \mathrm{m}^{2}\right)$ for a popular R1B house}

The unit cost of a popular wooden house has not yet been regulated by the ABNT. Thus, a choice was made to use the Basic Unit Cost $\left(\mathrm{BUC} / \mathrm{m}^{2}\right)$ normalized by the ABNT NBR 12721:2006 norm for conventional masonry constructions as a reference, considering that

Table 1. Stages of the proposed study.

\begin{tabular}{|c|c|c|}
\hline Implementation stages & $\begin{array}{l}\text { Systems, organizations, suppliers, } \\
\text { and collaborators involved }\end{array}$ & Results achieved \\
\hline $\begin{array}{l}1 \text { - Visit to Rio Branco to demonstrate } \\
\text { the project and sensitize the parties } \\
\text { involved in August } 2015\end{array}$ & $\begin{array}{l}\text { SINDUSMAD-AC; } \\
\text { SINDUSCON-AC; } \\
\text { FUNTAC; } \\
\text { FIEAC; } \\
10 \text { timber companies and sawmills; } \\
04 \text { construction material retailers. }\end{array}$ & $\begin{array}{l}\text { Forwarding of spreadsheets with } \\
\text { quantities of timber and other } \\
\text { construction materials of the PWH } \\
\text { project to attain market price } \\
\text { collection }\end{array}$ \\
\hline 2 - Market data collection & $\begin{array}{l}\text { Timber companies: Índia Porã; } \\
\text { Triângulo; Madeirense. } \\
\text { Retailers: Agroboi; Barriga Verde; } \\
\text { Parafusão. } \\
\text { Undergraduate student majoring in } \\
\text { Economics at UFAC. }\end{array}$ & $\begin{array}{l}\text { Monthly collection of prices from } \\
\text { timber companies, sawmills, and } \\
\text { construction material retailers }\end{array}$ \\
\hline $\begin{array}{l}3 \text { - Preparation of electrical, hydraulic } \\
\text { and sanitary projects }\end{array}$ & $\begin{array}{l}\text { Collaborating civil engineer, } \\
\text { professional registration no. } \\
\text { CREA - } 180.161 .895-0 \text {. }\end{array}$ & $\begin{array}{l}\text { Preparation of spreadsheets with } \\
\text { quantities of materials, based on the } \\
\text { projects, and treatment of all data } \\
\text { using Microsoft Excel } 2010 \text { software }\end{array}$ \\
\hline
\end{tabular}

Table 2. Technological characterization of the wood included in the study.

\begin{tabular}{|c|c|c|c|}
\hline Wood & Density & Durability & Use \\
\hline $\begin{array}{l}\text { Cumaru } \\
\text { Dipteryx odorata (Aubl.) } \\
\text { Willd. }\end{array}$ & $\begin{array}{l}\text { Heavy wood. Density at } \\
12 \% \text { moisture content of } \\
1.080 \mathrm{~kg} / \mathrm{m}^{3} \text { and green } \\
\text { density of } 1280 \mathrm{~kg} / \mathrm{m}^{3}\end{array}$ & $\begin{array}{l}\text { Resistant to fungi, insects, } \\
\text { and marine wood borers. } \\
\text { Ranging from } 10 \text { to } 22 \text { years } \\
\text { in contact with the soil }\end{array}$ & $\begin{array}{l}\text { External and internal } \\
\text { constructions, floors, among } \\
\text { others }\end{array}$ \\
\hline $\begin{array}{l}\text { Garapeira } \\
\text { Apuleia leiocarpa (Vogel) } \\
\text { J. F. Macbr }\end{array}$ & $\begin{array}{l}\text { Heavy wood. Density at } \\
12 \% \text { moisture content of } \\
880-900 \mathrm{~kg} / \mathrm{m}^{3} \text { and green } \\
\text { density of } 1250 \mathrm{~kg} / \mathrm{m}^{3}\end{array}$ & $\begin{array}{l}\text { Resistant to white- and } \\
\text { brown-rot fungi and insects; } \\
\text { weatherproof }\end{array}$ & $\begin{array}{l}\text { Joinery, furniture, sleepers, } \\
\text { boats, poles, piles, tool } \\
\text { handles, among others }\end{array}$ \\
\hline $\begin{array}{l}\text { Jatobá } \\
\text { Hymenaea courbaril L. }\end{array}$ & $\begin{array}{l}\text { Heavy wood. Density at } \\
12 \% \text { moisture content of } \\
890 \mathrm{~kg} / \mathrm{m}^{3} \text { and green density } \\
\text { of } 1240 \mathrm{~kg} / \mathrm{m}^{3}\end{array}$ & $\begin{array}{l}\text { Heart very resistant to fungi } \\
\text { and termites. Low resistance } \\
\text { to marine borers }\end{array}$ & $\begin{array}{l}\text { Civil construction, luxury } \\
\text { furniture, sleepers, truck } \\
\text { bodies, implements for trucks, } \\
\text { among others }\end{array}$ \\
\hline $\begin{array}{l}\text { Tauari } \\
\text { Couratari spp. }\end{array}$ & $\begin{array}{l}\text { Heavy wood. Density at } \\
12 \% \text { moisture content of } \\
610 \mathrm{~kg} / \mathrm{m}^{3} \text { and green density } \\
\text { of } 1100 \mathrm{~kg} / \mathrm{m}^{3}\end{array}$ & $\begin{array}{l}\text { Tendency to blue stain. } \\
\text { It should be used dry and } \\
\text { protected from moisture and } \\
\text { insects }\end{array}$ & $\begin{array}{l}\text { Civil and naval construction, } \\
\text { furniture, curved parts, } \\
\text { joinery, domestic utensils, } \\
\text { among others }\end{array}$ \\
\hline
\end{tabular}

Source: Prepared by the author based on Souza et al. $(2002,2014)$. 
the masonry and wooden construction projects are quite similar (ABNT, 2006).

Although the $\mathrm{BUC} / \mathrm{m}^{2}$ does not represent the final cost of a construction because it does not include items such as foundations and common area, it was considered as the basis for establishing the $\mathrm{FUC} / \mathrm{m}^{2}$ for the popular wooden house considering that the two measures are closely related. Both the $\mathrm{BUC} / \mathrm{m}^{2}$ and the $\mathrm{FUC} / \mathrm{m}^{2}$ seek to demonstrate the cost of a construction unit from the inputs used in it. Whereas the FUC/ $\mathrm{m}^{2}$ quantifies foundations, it does not address the cost of leasing equipment, which is considered in the $\mathrm{BUC} / \mathrm{m}^{2}$. Both can be used as a basis so that producers, consumers, financiers, and the State, as a subsidiary of housing programs for low-income populations, know and apply the minimum cost per square meter of a given construction unit.

According to the ABNT NBR 12721:2006 norm (ABNT, 2006), at least 12 basic items are needed to compose the $\mathrm{BUC} / \mathrm{m}^{2}$, which comprise the basic set of inputs, and include the cost of equipment, labor, and materials. ABNT lists each input together with the respective coefficient for each specific standard project, demonstrating that, through this coefficient, a series of correlated items is considered in the calculations. The coefficient presents the complete family of each material. When multiplied by the cost of the input family per standard project, the unit cost of a construction can be obtained for any state of the country (CBIC, 2013).

Owing to the lack of norms for a standard wooden house project, physical coefficients are also not available in the academic environment, which motivated the market cost estimate of the inputs needed for construction.

Thus, a mean was calculated for each item from the data provided by timber companies and retailers of construction materials using the Formula 1:

$\bar{P}=\frac{P_{1}+P_{2}+P_{3}+\ldots+P_{n-1}+P_{n}}{n}$

where: $\bar{P}=$ mean prices of suppliers per analyzed item; $n=$ number of suppliers that collaborated in the survey; and $P_{1}, P_{2}, P_{3}, \ldots, P_{n}=$ prices of items reported by each supplier.

After calculating the mean prices of individual inputs, the Formula 2 was created, which allows combination of all the data analyzed to form the Final Unit Cost of a Popular Wooden House:

$\frac{F U C}{m^{2}}=\frac{\bar{P} Q M_{C}+\overline{P Q} O M_{C S}+\bar{P} Q E H S_{S}+\overline{P Q} M O_{S}}{A}$

where: $\bar{P} Q M_{C}=$ mean prices of wood suppliers (market); $\overline{P Q} O M_{C S}=$ mean prices of other construction materials (market and SINAPI); $\bar{P} Q E H S_{S}=$ mean prices of electrical, hydraulic and sanitary material (SINAPI); $\overline{P Q} M O_{S}=$ mean cost of labor (SINAPI); and $A=$ area of a Popular Wooden House $=52 \mathrm{~m}^{2}$.

\section{RESULTS AND DISCUSSION}

After preparation of the spreadsheets containing the individual costs of timber, non-timber inputs, electrical, hydraulic and sanitary material, and labor, it was verified that the monthly variation in the period assessed was approximately $5 \%$ between trimesters due to price adjustments of the total inputs, except for labor. Therefore, for discussion, the mean cost was calculated for the period for each set of inputs needed for the project, as presented in Table 3 .

Figure 1 shows that the total mean cost of timber was $\mathrm{R} \$ 20,078.07$, distributed as a percentage.

The mean total cost for other inputs during the study months was $\mathrm{R} \$ 9,728.48$, as presented in Table 4 .

Table 5 lists the costs of electric, hydraulic and sanitary materials.

Figure 2 shows the percentage distribution of the final mean costs of non-timber materials described in Annex II of the PWH project, Annex I of Ordinance no. 318/2014 of the Brazilian Ministry of Cities, and

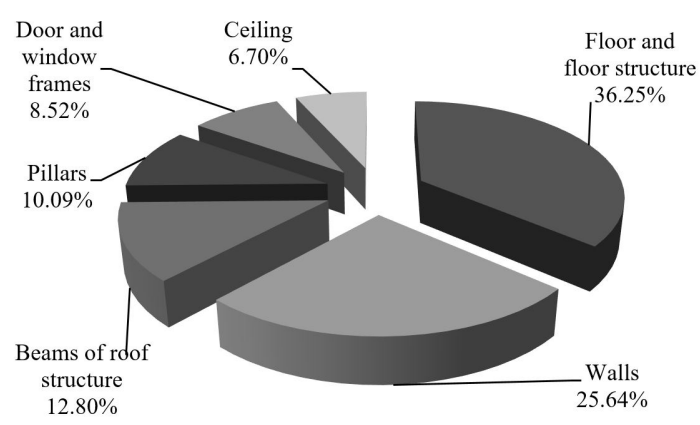

Figure 1. Percentage participation of timber batches for the construction of a Popular Wooden House. 
Table 3. Market cost of timber estimated from September 2015 to April 2016.

\begin{tabular}{|c|c|c|c|c|}
\hline Type of material & Unit & Quantity & $\begin{array}{c}\text { Mean unit } \\
\text { value } \\
\text { (R\$) }\end{array}$ & $\begin{array}{l}\text { Mean total } \\
\text { value (R\$) }\end{array}$ \\
\hline Pillars & & & & $2,025.33$ \\
\hline $10 \times 10 \times 331 \mathrm{~cm}$ pillar & piece & 3 & 87.32 & 261.92 \\
\hline $15 \times 15 \times 356 \mathrm{~cm}$ pillar & piece & 9 & 176.24 & $1,586.15$ \\
\hline Pillar complement $(15 \times 15 \times 85 \mathrm{~cm})$ & piece & 3 & 59.09 & 177.26 \\
\hline Beams of roof structure & & & & $2,569.59$ \\
\hline Slats $(1.5 \times 5 \mathrm{~cm})$ & $\mathrm{m}$ & 220 & 1.70 & 372.90 \\
\hline Rafters $(5 \times 7 \times 435 \mathrm{~cm})$ & piece & 10 & 28.75 & 287.53 \\
\hline Rafters $(5 \times 7 \times 360 \mathrm{~cm})$ & piece & 24 & 22.79 & 546.93 \\
\hline Rafters $(5 \times 7 \times 205 \mathrm{~cm})$ & piece & 7 & 13.42 & 93.93 \\
\hline Purlins $(5 \times 15 \times 205 \mathrm{~cm})$ & piece & 2 & 44.73 & 89.47 \\
\hline Purlins $(5 \times 15 \times 280 \mathrm{~cm})$ & piece & 5 & 56.19 & 280.98 \\
\hline Purlins $(5 \times 15 \times 375 \mathrm{~cm})$ & piece & 3 & 80.20 & 240.58 \\
\hline Purlins $(5 \times 15 \times 481 \mathrm{~cm})$ & piece & 1 & 135.64 & 135.64 \\
\hline Purlins $(5 \times 15 \times 428 \mathrm{~cm})$ & piece & 5 & 79.87 & 399.32 \\
\hline Battens for the porch rafters $(2 \times 10 \times 202 \mathrm{~cm})$ & piece & 8 & 15.29 & 122.31 \\
\hline Walls & & & & $5,147.83$ \\
\hline Panel fixation/purlins $(2 \times 10 \times 360 \mathrm{~cm})$ & piece & 10 & 20.51 & 205.04 \\
\hline Panel fixation/purlins $(2 \times 10 \times 270 \mathrm{~cm})$ & piece & 10 & 18.33 & 183.31 \\
\hline Panel fixation/purlins $(2 \times 10 \times 180 \mathrm{~cm})$ & piece & 2 & 15.74 & 31.49 \\
\hline Panel fixation/purlins $(2 \times 10 \times 90 \mathrm{~cm})$ & piece & 4 & 6.33 & 25.45 \\
\hline Panel fixation/purlins $(5 \times 5 \times 90 \mathrm{~cm})$ & piece & 2 & 5.74 & 11.48 \\
\hline Wood-joint or panel fixation/pillars $(2 \times 4 \times 255 \mathrm{~cm})$ & $\mathrm{m}$ & 92 & 4.12 & 378.73 \\
\hline Wood-joint or panel fixation/panel $(2 \times 7 \times 255 \mathrm{~cm})$ & $\mathrm{m}$ & 118 & 6.56 & 773.88 \\
\hline Doorstop $(5 \times 8 \times 255 \mathrm{~cm})$ & piece & 8 & 18.76 & 150.07 \\
\hline Doorstop $(5 \times 8 \times 83 \mathrm{~cm})$ & piece & 4 & 7.14 & 28.55 \\
\hline Wood board separators $(2 \times 2 \times 15 \mathrm{~cm})$ & piece & 36 & 0.84 & 30.00 \\
\hline Fixing batten $(2 \times 10 \times 85 \mathrm{~cm})$ & piece & 4 & 4.07 & 16.27 \\
\hline Lining boards $(2 \times 15 \times 83 \mathrm{~cm})$ & piece & 459 & 5.58 & $2,560.67$ \\
\hline Window/door shutters $(1 \times 8 \times 83 \mathrm{~cm})$ & piece & 63 & 0.55 & 34.86 \\
\hline Window/door shutters $(1.5 \times 8 \times 76 \mathrm{~cm})$ & piece & 36 & 0.64 & 22.92 \\
\hline Panel support $(5 \times 5 \times 255 \mathrm{~cm})$ & piece & 14 & 5.81 & 81.36 \\
\hline Slats or shutters of the gables $(2 \times 15 \times 590 \mathrm{~cm})$ & piece & 16 & 16.90 & 270.40 \\
\hline Slats or shutters of the gables $(2 \times 15 \times 108.15 \mathrm{~cm})$ & piece & 4 & 4.42 & 17.69 \\
\hline Slats or shutters of the gables $(2 \times 15 \times 135.8 \mathrm{~cm})$ & piece & 4 & 5.86 & 23.44 \\
\hline Slats or shutters of the gables $(2 \times 15 \times 161.5 \mathrm{~cm})$ & piece & 4 & 5.29 & 21.15 \\
\hline Slats or shutters of the gables $(2 \times 15 \times 188.15 \mathrm{~cm})$ & piece & 4 & 5.56 & 22.23 \\
\hline Slats or shutters of the gables $(2 \times 15 \times 214.8 \mathrm{~cm})$ & piece & 4 & 6.65 & 26.60 \\
\hline Slats or shutters of the gables $\mathrm{s}(2 \times 15 \times 241.5 \mathrm{~cm})$ & piece & 4 & 6.92 & 27.68 \\
\hline Slats or shutters of the gables $(2 \times 15 \times 268.15 \mathrm{~cm})$ & piece & 4 & 8.36 & 33.43 \\
\hline Slats or shutters of the gables $(2 \times 15 \times 294.8 \mathrm{~cm})$ & piece & 4 & 8.62 & 34.47 \\
\hline Slats or shutters of the gables $(2 \times 15 \times 282 \mathrm{~cm})$ & piece & 8 & 8.49 & 67.89 \\
\hline Slats or shutters of the gables $(2 \times 15 \times 292.5 \mathrm{~cm})$ & piece & 8 & 8.60 & 68.77 \\
\hline Door and window frames & & & & $1,710.79$ \\
\hline Flat part $(5 \times 8 \times 83 \mathrm{~cm})$ & piece & 4 & 8.11 & 32.43 \\
\hline Frame $(5 \times 8 \times 109.5 \mathrm{~cm})$ & piece & 14 & 9.62 & 134.63 \\
\hline Frame $(5 \times 8 \times 83 \mathrm{~cm})$ & piece & 14 & 8.40 & 117.60 \\
\hline Shutter side $(2 \times 8 \times 36 \mathrm{~cm})$ & piece & 8 & 2.18 & 17.37 \\
\hline
\end{tabular}

Source: Prepared by the author based on Annex II of the Popular Wooden House Project of Melo et al. (2002). 
Table 3. Continued...

\begin{tabular}{|c|c|c|c|c|}
\hline Type of material & Unit & Quantity & $\begin{array}{c}\text { Mean unit } \\
\text { value } \\
\text { (R\$) }\end{array}$ & $\begin{array}{l}\text { Mean total } \\
\text { value (R\$) }\end{array}$ \\
\hline Panel batten $(5 \times 5 \times 83 \mathrm{~cm})$ & piece & 14 & 4.67 & 65.33 \\
\hline Panel batten $(5 \times 8 \times 83 \mathrm{~cm})$ & piece & 54 & 6.94 & 374.85 \\
\hline Panel support $(5 \times 5 \times 255 \mathrm{~cm})$ & piece & 54 & 13.30 & 717.98 \\
\hline Board $(2 \times 15 \times 83 \mathrm{~cm})$ & piece & 42 & 5.97 & 250.60 \\
\hline Ceiling & & & & $1,345.24$ \\
\hline Joist support $(3 \times 3 \times 360 \mathrm{~cm})$ & piece & 7 & 10.83 & 75.79 \\
\hline Joist support $(3 \times 3 \times 177.5 \mathrm{~cm})$ & piece & 1 & 3.12 & 3.12 \\
\hline Ceiling fixing bar $(5 \times 6 \times 280 \mathrm{~cm})$ & piece & 29 & 15.77 & 457.43 \\
\hline Ceiling fixing bar $(5 \times 6 \times 250 \mathrm{~cm})$ & piece & 3 & 14.90 & 44.69 \\
\hline Ceiling fixing bar $(5 \times 6 \times 100 \mathrm{~cm})$ & piece & 2 & 5.97 & 11.93 \\
\hline Ceiling boards $(1 \times 10 \mathrm{~cm})$ & $\mathrm{m}^{2}$ & 50 & 9.55 & 477.28 \\
\hline Ceiling skirting & $\mathrm{m}$ & 55 & 5.00 & 275.00 \\
\hline Floor and floor structure & & & & $7,279.29$ \\
\hline Floor sleeper $(5 \times 15 \times 270 \mathrm{~cm})$ & piece & 5 & 49.68 & 248.36 \\
\hline Floor sleeper $(5 \times 15 \times 140 \mathrm{~cm})$ & piece & 2 & 33.78 & 67.55 \\
\hline Floor sleeper $(5 \times 15 \times 360 \mathrm{~cm})$ & piece & 5 & 64.42 & 322.08 \\
\hline Floor sleeper $(5 \times 15 \times 190 \mathrm{~cm})$ & piece & 1 & 39.39 & 39.39 \\
\hline Floor sleeper $(5 \times 15 \times 247.5 \mathrm{~cm})$ & piece & 1 & 47.76 & 47.76 \\
\hline Bar support $(5 \times 7 \times 352 \mathrm{~cm})$ & piece & 7 & 26.11 & 182.76 \\
\hline Bar support $(5 \times 7 \times 132 \mathrm{~cm})$ & piece & 2 & 8.99 & 17.98 \\
\hline Bar support $(5 \times 7 \times 175 \mathrm{~cm})$ & piece & 2 & 13.43 & 26.86 \\
\hline Bar support $(5 \times 7 \times 233.5 \mathrm{~cm})$ & piece & 1 & 16.78 & 16.78 \\
\hline Longboard bar support $(5 \times 11 \times 280 \mathrm{~cm})$ & piece & 27 & 37.99 & $1,025.78$ \\
\hline Longboard bar support $(5 \times 11 \times 100 \mathrm{~cm})$ & piece & 2 & 13.56 & 27.12 \\
\hline Longboard bar support $(5 \times 11 \times 75 \mathrm{~cm})$ & piece & 6 & 11.64 & 69.83 \\
\hline Floor sleeper supports $(4 \times 15 \times 42.5 \mathrm{~cm})$ & piece & 23 & 21.38 & 491.63 \\
\hline Floor sleeper supports $(4 \times 10 \times 42.5 \mathrm{~cm})$ & piece & 04 & 8.66 & 34.64 \\
\hline Lining floor board $(2 \times 15 \mathrm{~cm})$ & $\mathrm{m}^{2}$ & 63 & 59.85 & $3,770.55$ \\
\hline $5 \mathrm{~cm}$ wall skirting board & $\mathrm{m}$ & 45 & 6.50 & 292.50 \\
\hline Stairs $(5 \times 18 \times 110 \mathrm{~cm})$ & unit & 04 & 35.48 & 141.88 \\
\hline Stairs $(3 \times 30 \times 152 \mathrm{~cm})$ & unit & 02 & 45.56 & 91.11 \\
\hline Stairs $(3 \times 30 \times 82 \mathrm{~cm})$ & unit & 02 & 21.72 & 43.43 \\
\hline Porch body guard $(5 \times 11 \times 400 \mathrm{~cm})$ & piece & 07 & 31.50 & 220.50 \\
\hline Porch body guard $(5 \times 11 \times 300 \mathrm{~cm})$ & piece & 04 & 25.20 & 100.80 \\
\hline Total cost of wood & & & & $20,078.07$ \\
\hline
\end{tabular}

Source: Prepared by the author based on Annex II of the Popular Wooden House Project of Melo et al. (2002).

the cost of electrical, hydraulic and sanitary materials, after attainment of the respective projects (Brasil, 2014).

The final cost of labor required to provide construction services was $R \$ 16,032.77$. The number of man-hours for these professionals was calculated following guidance of the architect of the PWH project and the civil engineer who designed the complementary projects: electric, hydraulic and sanitary, as shown in Table 6.

Figure 3 depicts the quantitative percentage participation in the composition of the Final Unit Cost of a wooden house with all the inputs indispensable to its construction. The final unit cost for the months analyzed was $\mathrm{R} \$ 934.52 / \mathrm{m}^{2}$, totaling $\mathrm{R} \$ 48,595.04$.
The Construction Industry Union of the State of Acre (SINDUSCON-AC) does not survey the $\mathrm{BUC} / \mathrm{m}^{2}$ for its constructions; therefore, data on the $\mathrm{BUC} / \mathrm{m}^{2}$ of a two-bedroom R1B house disclosed by the of Industry and Commerce Union of the State of Amazonas (SINDUSCON-AM) was used to compare with the $\mathrm{FUC} / \mathrm{m}^{2}$ composed for popular wooden house, as shown in Table 7 (CBIC, 2016, 2019a).

However, in order to compare the value of the $\mathrm{BUC} / \mathrm{m}^{2}$ disclosed by the SINDUSCON-AM with what would be a similar $\mathrm{BUC} / \mathrm{m}^{2}$ for the same construction in the state of Acre, a BUC/ $\mathrm{m}^{2}$ was composed for that state using the R1B project: low-cost, single-family 
Table 4. Market cost of other construction materials estimated at retailers from September 2015 to April 2016.

\begin{tabular}{|c|c|c|c|c|}
\hline Type of material & Unit & Quantity & $\begin{array}{c}\text { Mean unit } \\
\text { value } \\
\text { (R\$) }\end{array}$ & $\begin{array}{l}\text { Mean total } \\
\text { value (R\$) }\end{array}$ \\
\hline Doors and windows & & & & $2,153.31$ \\
\hline Flush wood door for painting $80 \times 210 \times 3.5 \mathrm{~cm}$ & unit & 2 & 117.62 & 235.23 \\
\hline Flush plywood door for painting $80 \times 210 \times 3.5 \mathrm{~cm}$ & unit & 2 & 185.47 & 370.94 \\
\hline Flush wood door for painting $60 \times 210 \times 3.5 \mathrm{~cm}$ & unit & 1 & 110.30 & 110.30 \\
\hline Wooden pivoting window, without shutter, with trim & unit & 7 & 150.67 & $1,054.66$ \\
\hline Wooden swing window, regional 3a type & unit & 1 & 94.07 & 94.07 \\
\hline $\begin{array}{l}\text { Built-in door lock for external door, door handle, and metal } \\
\text { mirror }\end{array}$ & unit & 2 & 31.94 & 63.88 \\
\hline Built-in door lock for internal door, popular line & unit & 1 & 24.83 & 24.83 \\
\hline Built-in door lock for bathroom door, popular line & unit & 1 & 24.16 & 24.16 \\
\hline Steel and/or iron hinge, 3 " $\times 2 \hat{a}^{1} / 2 ", 1.2$ to $1.8 \mathrm{~mm}$ thick & unit & 26 & 6.74 & 175.24 \\
\hline Roof & & & & $4,345.17$ \\
\hline Half-round ceramic roof tile, $47 \mathrm{~cm}$, coverage 26 pieces $/ \mathrm{m}^{2}$ & $\mathrm{~m}$ & 2360 & 1.78 & $4,192.93$ \\
\hline Ceramic roof tile ridge, $41 \mathrm{~cm}$, coverage 3 pieces $/ \mathrm{m}$ & piece & 30 & 5.09 & 152.24 \\
\hline Masonry and foundation & & & & $2,136.93$ \\
\hline 8-hole ceramic block, de $9 \times 19 \times 19 \mathrm{~cm}$ & unit & 660 & 0.55 & 363.00 \\
\hline Portland composite cement, CP II-32 (50 kg bag) & unit & 18 & 34.98 & 629.70 \\
\hline Crushed stone no. 1 (9.5 to $19 \mathrm{~mm}$ ), quarry supplier & $\mathrm{m}^{3}$ & 2 & 228.44 & 456.88 \\
\hline Crushed stone no. 2 (19 to $38 \mathrm{~mm}$ ), quarry supplier & $\mathrm{m}^{3}$ & 3 & 225.09 & 675.26 \\
\hline Medium sand, deposit supplier & $\mathrm{m}^{3}$ & 0.3 & 40.31 & 12.09 \\
\hline Painting & & & & 806.50 \\
\hline Premium matte white acrylic paint & gal & 6 & 65.05 & 390.28 \\
\hline Termiticide, Pentox & 1 & 5 & 29.68 & 148.10 \\
\hline Bright synthetic varnish & 1 & 7.2 & 17.98 & 129.43 \\
\hline Turpentine diluent solvent & 1 & 5 & 10.30 & 51.50 \\
\hline Paint roller & unit & 3 & 25.15 & 75.44 \\
\hline Sandpaper for wall or wood, no. 120 & unit & 5 & 0.55 & 2.75 \\
\hline Cotton waste & $\mathrm{kg}$ & 1 & 9.00 & 9.00 \\
\hline Screws, bolts, nuts, nails and hardware & & & & 306.57 \\
\hline French head galvanized bolt $3 / 8$ " $(9.5 \times 130 \mathrm{~mm})$ nut/washer & unit & 49 & 1.36 & 66.64 \\
\hline French head galvanized bolt $3 / 8$ " $(9.5 \times 180 \mathrm{~mm})$ nut/washer & unit & 19 & 1.76 & 33.44 \\
\hline Slotted screw $5.5 \times 75 \mathrm{~mm}$ & unit & 48 & 2.01 & 96.48 \\
\hline S10 bushing & unit & 08 & 0.39 & 3.12 \\
\hline Nail $15 \times 15$ & $\mathrm{~kg}$ & 03 & 10.71 & 31.13 \\
\hline Nail $17 \times 21$ & $\mathrm{~kg}$ & 02 & 11.42 & 22.84 \\
\hline Nail $18 \times 30$ & $\mathrm{~kg}$ & 04 & 13.23 & 52.92 \\
\hline Total cost of other construction materials & & & & $9,728.48$ \\
\hline
\end{tabular}

Source: Prepared by the author based on Annex II of the Popular Wooden House Project of Melo et al. (2002).

house comprising one floor with two bedrooms, living room, bathroom, kitchen, and wash area, in $51.94 \mathrm{~m}^{2}$ (ABNT, 2006).

Table 8 shows the cost of materials, labor, administrative expenses, and equipment, regulated by the norm of batch of inputs, collected using the SINAPI in Rio Branco, Acre state, from February to April 2016 and September to November 2016.

The cost per square meter for the construction of low-cost dwellings in the state of Amazonas is similar to that in Rio Branco, Acre state, with an approximate difference of $\mathrm{R} \$ 45.00 / \mathrm{m}^{2}$.

Owing to the absence of studies addressing wooden constructions exclusively, other types of popular construction intended to the low-income population were taken as reference as a solution to reduce the housing deficit in localities where this theme is studied.

In Brazilian constructions, there is predominance of the use of masonry, whether in ceramic or concrete brick, disregarding the possibility of building a good, 
single-family dwelling with affordable cost and thermal comfort for the low-income population. Prefabricated wooden houses constructed with wood from the Amazon forest are a viable alternative; because of their thin walls (3-6 cm thick), they adapt to regions with warmer climate (Souza, 2013).

In analysis of the constructive potential of the Steel Frame and Wood Frame light systems in the production of low-cost housing, in recent years, an industrial park has been implemented in Brazil to produce components of these systems, particularly Steel Frame, with the creation of manuals, financing of technology, dissemination, and training of professionals. The following aspects are considered relevant: lightness, constructive speed, and final quality of the construction - superior to the conventional masonry constructions (Meirelles et al., 2012).

Table 5. Market cost of electric, hydraulic and sanitary materials estimated using the SINAPI ${ }^{\star}$ from September 2015 to April 2016.

\begin{tabular}{ccc}
$\begin{array}{c}\text { SINAPI } \\
\text { code }\end{array}$ & $\begin{array}{c}\text { Type of material/ } \\
\text { Installation }\end{array}$ & $\begin{array}{c}\text { Total cost } \\
(\mathbf{R} \$)\end{array}$ \\
\hline Various & Hydraulic installations & $1,133.99^{\star}$ \\
Various & Sanitary installations & $909.42^{\star}$ \\
\hline Various & Electrical installations & $712.38^{\star}$ \\
\hline & Total cost of materials & $\mathbf{2 , 7 5 5 . 7 9}$ \\
\hline
\end{tabular}

${ }^{*}$ SINAPI $=$ National System of Costs Survey and Indexes of Construction (Brasil, 2019).
According to the studies by Grigoletti et al. (2008), construction of low-cost housing is a permanent challenge in Brazil because, whereas costs must be

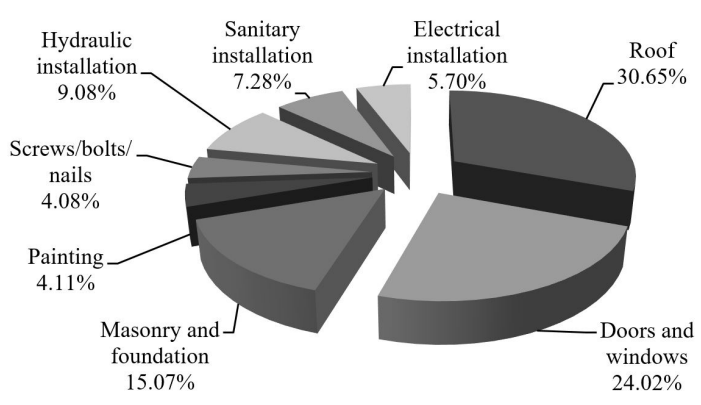

Figure 2. Percentage participation of other construction materials in the cost composition of a Popular Wooden House.

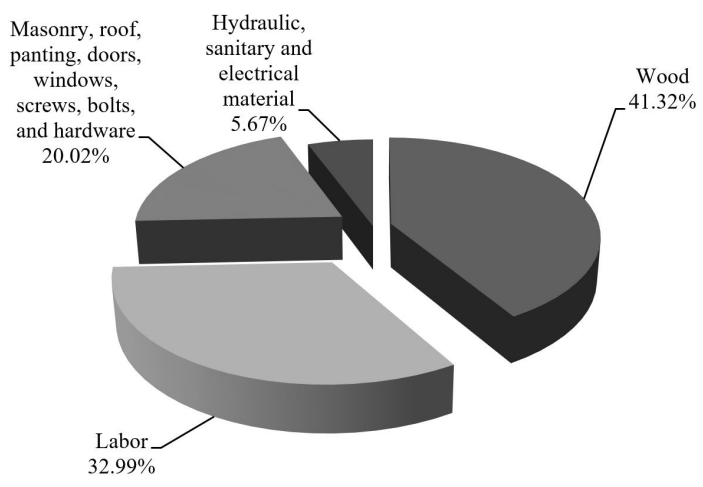

Figure 3. Percentage participation in the Final Unit Cost $\left(\mathrm{FUC} / \mathrm{m}^{2}\right)$ of the Popular Wooden House.

Table 6. Quantitative labor cost for the construction of a Popular Wooden House.

\begin{tabular}{|cccccc|} 
Quantity & Professional & $\begin{array}{c}\text { Man-hours/ } \\
\text { day }\end{array}$ & $\begin{array}{c}\text { Total hours/ } \\
\text { professional }\end{array}$ & $\begin{array}{c}\text { Cost per hour } \\
\text { (R\$) }\end{array}$ & $\begin{array}{c}\text { Total cost/ } \\
\text { professional } \\
\text { (R\$) }\end{array}$ \\
\hline 2 & Mason & $8 \times 8$ & 128 & 13.97 & $1,787.73$ \\
\hline 1 & Hod carrier & $8 \times 8$ & 64 & 10.17 & 650.67 \\
\hline 4 & Carpenter & $8 \times 15$ & 480 & 13.97 & $6,704.00$ \\
\hline 2 & Carpenter's assistant & $8 \times 15$ & 240 & 10.49 & $2,517.60$ \\
\hline 1 & Roofer & $8 \times 5$ & 40 & 12.08 & 483.07 \\
\hline 1 & Painter & $8 \times 8$ & 64 & 13.97 & 893.97 \\
\hline 1 & Painter's assistant & $8 \times 8$ & 64 & 10.49 & 671.36 \\
\hline 1 & Plumber & $8 \times 8$ & 64 & 13.97 & 893.97 \\
\hline 1 & Plumber's assistant & $8 \times 8$ & 64 & 10.49 & 671.36 \\
\hline Total cost of labor & Electrician & $8 \times 4$ & 32 & 13.97 & 446.93 \\
\hline
\end{tabular}

Source: Prepared by the author based on the professional market survey data. 
Table 7. Comparison of costs in $\mathrm{R} \$ / \mathrm{m}^{2}$ between wooden and masonry houses.

\begin{tabular}{|c|c|c|c|c|c|}
\hline \multirow{2}{*}{$\begin{array}{c}\text { Month } \\
\text { and } \\
\text { year }\end{array}$} & \multicolumn{2}{|c|}{$\begin{array}{c}52 \mathrm{~m}^{2} \text { Popular Wooden House in Rio } \\
\text { Branco, Acre state }\end{array}$} & \multicolumn{2}{|c|}{$\begin{array}{c}51.94 \mathrm{~m}^{2} \text { Conventional Masonry } \\
\text { House in Amazonas state }\end{array}$} & \multirow[t]{2}{*}{ Difference in \% } \\
\hline & $\mathrm{FUC}^{1} / \mathrm{m}^{2}$ & $\mathbf{R} \$$ & $\mathrm{BUC}^{2} / \mathrm{m}^{2}$ & R\$ & \\
\hline Sep 2015 & 917.21 & $47,694.92$ & $1,291.51$ & $67,081.03$ & 28.98 \\
\hline Oct 2015 & 914.29 & $47,543.08$ & $1,293.93$ & $67,206.72$ & 29.34 \\
\hline Nov 2015 & 918.83 & $47,779.16$ & $1,296.86$ & $67,358.91$ & 29.15 \\
\hline Feb 2016 & 961.07 & $49,975.64$ & $1,300.69$ & $67,557.84$ & 26.11 \\
\hline Mar 2016 & 950.88 & $49,445.76$ & $1,302.23$ & $67,637.83$ & 26.98 \\
\hline Apr 2016 & 944.84 & $49,131.68$ & $1,308.71$ & $67,974.40$ & 27.80 \\
\hline Mean & 934.52 & $48,595.04$ & $1,298.98$ & $67,469.45$ & 28.06 \\
\hline
\end{tabular}

${ }^{1} \mathrm{FUC}=$ Final Unit Cost; ${ }^{2} \mathrm{BUC}=$ Basic Unit Cost. Source: Prepared by the author based on data disclosed by at the BUC website (CBIC 2016, 2019a).

kept between US\$3000-4000, the housing deficit is excessively high and the financial resources for housing programs are limited. The Alvorada House project prototype was built in Porto Alegre, mainly composed of cement-based brick, with wooden doors, windows, and arbor/porch. The construction was completed in 2003 and has undergone several evaluations regarding the sustainable strategies employed.

Considering that the study of Grigoletti et al. (2008) addressed the architectural aspects of a popular house, the final cost of construction for April 2016 (exchange rate on April 15, $2016=$ US\$ 1.00/R \$ 3.52) would be $\mathrm{R} \$ 14,108.00$ for a $48 \mathrm{~m}^{2}$ house (FinanceOne, 2017).

The study by Grigoletti et al. (2008) did not include estimate of construction costs standardized by the $\mathrm{ABNT}$, and the amount reported is considerably lower than the actual market prices for housing construction.

Analysis of several construction technologies using sustainability indicators and final costs of single-family housing in Zurich, Switzerland, demonstrated that construction costs are a determining factor for the success and implementation of a constructive technology in the market. Affordable housing is defined as that with cost up to US $\$ 200.00 / \mathrm{m}^{2}$, including direct and indirect costs and all details associated with finishing (Wallbaum et al., 2012).

Along this study, considering a $52 \mathrm{~m}^{2}$ house as standard, its final cost would be US\$10,400.00, which for April 2016 (exchange rate on April 15, $2016=$ US\$1.00/R \$ 3.52) would be of $R \$ 36,680.80$ (FinanceOne, 2017).

A project using Fiber Reinforced Cement Compound (FRCC) was developed for the construction of popular dwellings to serve the low-income populations of the Pacific Islands. The project consists of a modular pre-molded system, designed to reduce unit costs and provide housing built through self-construction, using the local manpower of the homeowners, which does not require specialized qualification, only technical assistance from manufacturing to final assembly of the construction (Rockwood et al., 2015).

In Hong Kong, USA, public housing became a political priority as of 1953 , after a fire had left approximately 53,000 people homeless. In 2003, with the great outbreak of respiratory diseases caused by the insalubrity conditions of the public houses $(\mathrm{PH})$, a process to modernize the dwellings aiming to improve the sanitary and environmental conditions of the city was initiated. In the same year, the public rental housing program (PRH) was launched and the proposal is to house 3.5 million people in approximately 271 thousand PRHs by 2023 (Deng et al., 2016).

In Italy, social housing ( $\mathrm{SH}$ ) has been on the government's agenda of housing programs for decades, especially after the World War II. As of the 1980s, the Italian housing issue has been neglected, leaving the task of providing affordable housing to cooperative enterprises, favoring an increase in private property rate. In the past years, with the international real estate crisis, the public investments aimed at that sector of the society have been minimal. Since 2010, public-private partnerships (PPP) have been initiated for investments in the country's housing sector, encouraged by subsidies to funders (Copiello, 2016).

It is worth discussing the comparison between the cost of a residential unit developed in Rio Branco by 


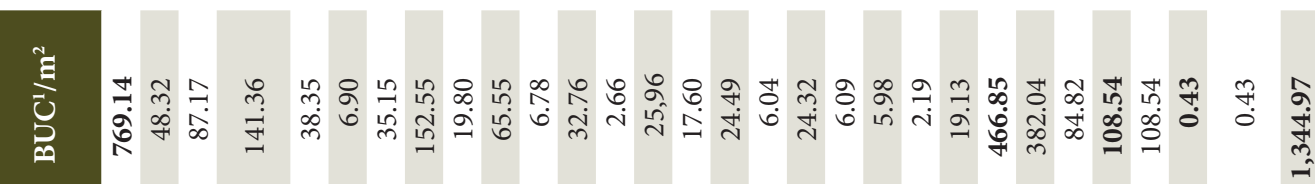

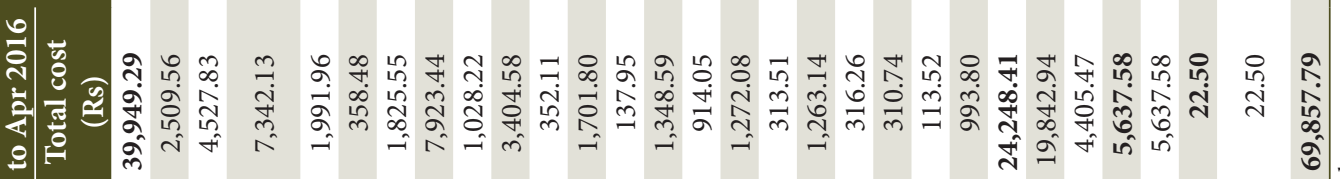
है:

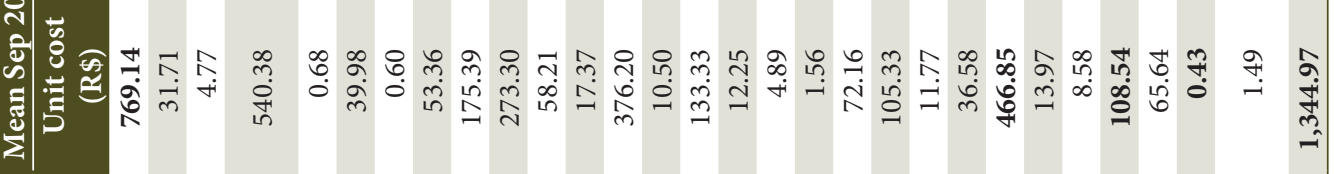

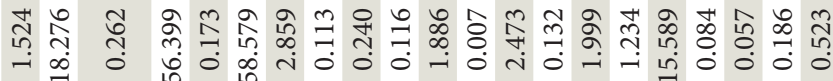

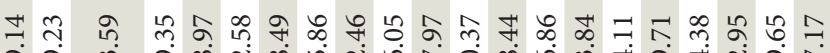

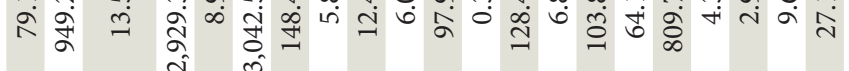

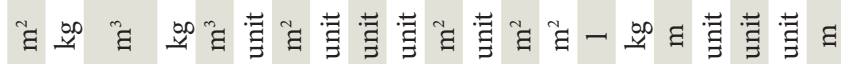

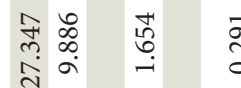

우 운

के

I

రิن

(5)

预

घ

$\stackrel{9}{\longrightarrow}$

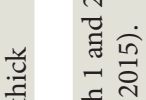

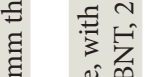

氖定

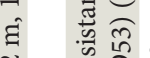

กิ कूँ

× ํํํㅂ

Ұ 远

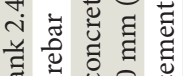

들

चै है

$\times$

辛

iิ

घ

ถู

घี

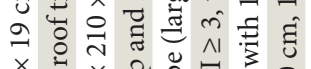

×

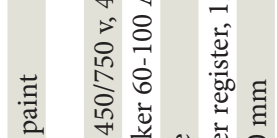

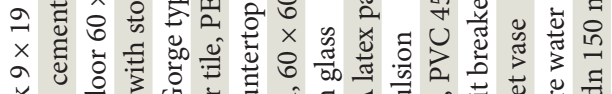

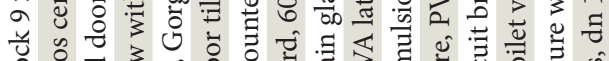

○.

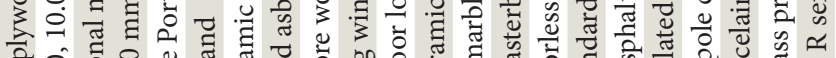
के

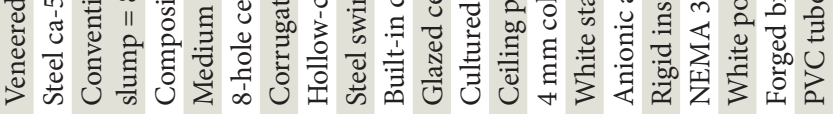

营

先

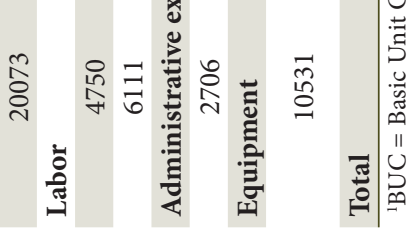



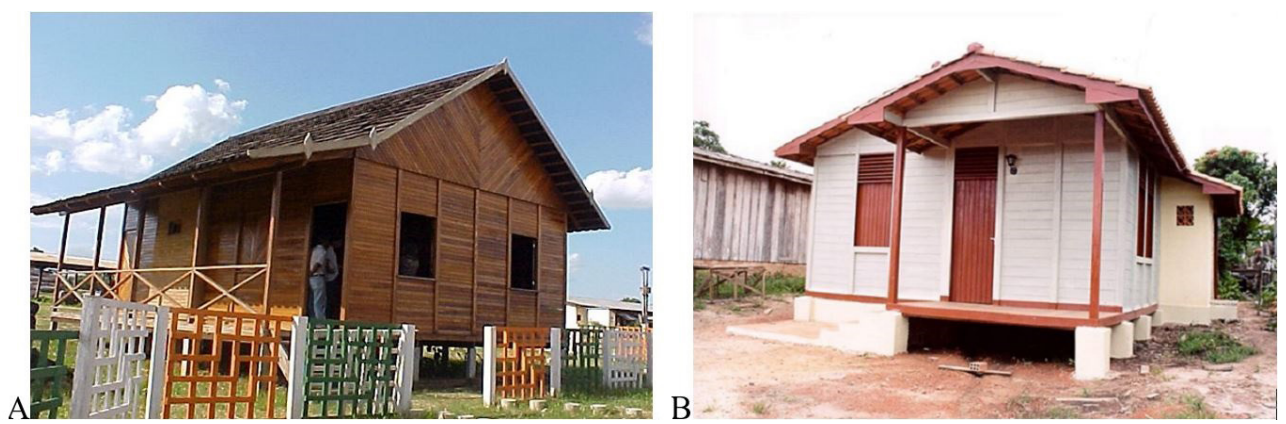

Figure 4. (A) Picture of the Citizen Housing Project prototype developed by FUNTAC (2003); (B) Picture of a Popular Wooden House taken in Pimenta Bueno, Rondônia state (IBAMA; LPF, 2002).

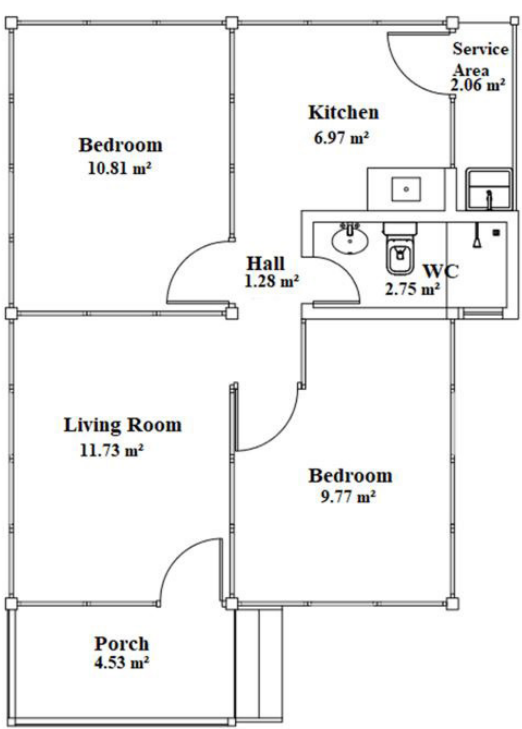

Popular Wooden Housing Project Floor Plan

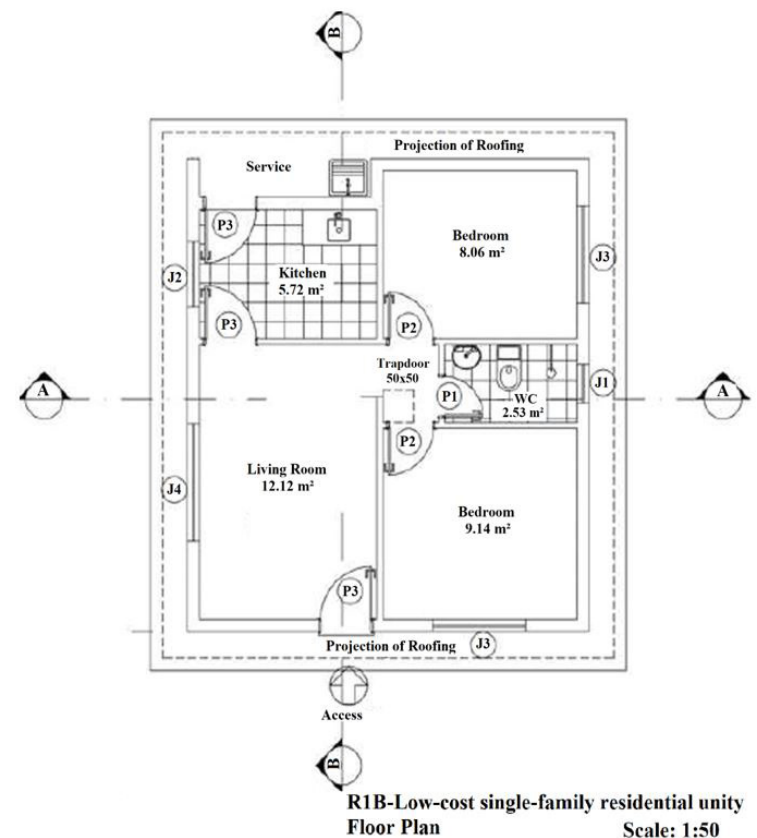

Figure 5. Comparison between the floor plans of the Popular Wooden House and that of conventional popular masonry houses.

the FUNTAC, through the Citizen Housing Project, which was of $\mathrm{R} \$ 431.10 / \mathrm{m}^{2}$ updated to April 2016 according to the National Civil Construction Index (INCC) and that of the $\mathrm{FUC} / \mathrm{m}^{2}$ of a Popular Wooden House, which was of $\mathrm{R} \$ 934.52 / \mathrm{m}^{2}$ on average in the period studied. Figure 4 illustrates the two constructions (CBIC, 2013, 2019b).

The final cost of the Citizen Housing Project was composed without considering the cost of labor, roof tiles, hardware, and other materials that were detailed in the PWH project, which justifies the difference observed, because the cost of materials and labor in popular construction exceeds $90 \%$ of the total cost.
Ahead, in Figure 5, are the floor plans of the Popular Wooden House originating from the study project and the conventional masonry house used by ABNT. It can be observed that the construction proposals for the Popular Wooden Houses and those regulated by $A B N T$ are similar, differing in the type of material used and the final cost of construction.

\section{CONCLUSION}

The final construction cost of a single-family dwelling in Brazil, calculated through the application of the $\mathrm{BUC} / \mathrm{m}^{2}$ methodology, is quite high; however, the 
Popular Wooden Housing ( $\mathrm{PWH}$ ) project is viable and feasible aiming insertion in the National Rural Housing Program (HRHP) if the final cost of construction is considered, which was $28.06 \%$ less costly than that of conventional masonry houses.

\section{ACKNOWLEDGEMENTS}

The authors would like to thank the Forest Products Laboratory of the Brazilian Forest Service/Ministry of the Environment for the partnership and data made available for this study. Special thanks are extended to the Forest Engineering Department of University of Brasilia for the cooperation and the Technology Foundation of the State of Acre for the support and material made available for the study. Finally, acknowledgement is due to loggers and retailers of construction materials in Rio Branco, Acre, for providing field data research and to FLORAM and its collaborators for the article reviews.

\section{SUBMISSION STATUS}

Received: 18 may. 2017

Accepted: 6 apr. 2018

\section{CORRESPONDENCE TO}

\section{Maria de Fátima Lima}

Serviço Florestal Brasileiro - SFB, SCEN Trecho

2, Lote 4 - L-4 Norte, Asa Norte, CEP 70818-900, Brasília, DF, Brasil

e-mail: fatima.lima@florestal.gov.br

\section{REFERENCES}

Associação Brasileira de Normas Técnicas - ABNT. NBR-12721: avaliação de custos unitários de construção para incorporação imobiliária e outras disposições. Rio de Janeiro: ABNT; 2006.

Associação Brasileira de Normas Técnicas - ABNT. NBR8953: concreto para fins estruturais, classificação pela massa específica por grupos de resistência e consistência. Rio de Janeiro: ABNT; 2015.

Brasil. Constituição da República Federativa do Brasil, de outubro de 1988. Dá nova redação ao art. $6^{\circ}$ da Constituição Federal, para introduzir a moradia como direito social. Brasília. Redação dada pela Emenda Constitucional no 26 de 2000 [Internet]. Brasília; 1988 [cited 2017 Jan 18]. Available from: http://www.planalto.gov.br/ccivil_03/constituicao/ constituicaocompilado.htm
Brasil. Ministério das Cidades. Portaria $n^{\circ} 318$, de junho de 2014. Dispõe sobre o uso de madeira na construção e reforma de habitação, no âmbito do Programa Nacional de Habitação Rural - PNHR, integrante do Programa Minha Casa, Minha Vida - PMCMV. Diário Oficial da União. Brasília, 13 de junho de 2014; Seção 1. p. 45.

Brasil. Ministério das Cidades. Programa Nacional de Habitação Rural [Internet]. 2016 [cited 2016 June 21]. Available from: http://www.cidades.gov.br/habitacao/ pmomv-pnhr

Brasil. Caixa Econômica Federal. Sistema Nacional de Pesquisa de Custos e Índices da Construção Civil - SINAPI [Internet]. 2019 [cited 2019 Mar 14]. Available from: http:// www.caixa.gov.br/poder-público/apoio-poder-publico/ sinapi/Paginas/default.aspx

Câmara Brasileira da Indústria da Construção - CBIC. Caracterização dos projetos-padrão conforme a ABNT NBR 12721:2006 [online]. 2013 [cited 2016 Dec 19]. Available from: http://www.cub.org.br/projetos-padrão

Câmara Brasileira da Indústria da Construção - CBIC. $\mathrm{CUB} / \mathrm{m}^{2}$. CUB Estadual Amazonas [online]. Manaus: SINDUSCON-AM; 2016 [cited 2016 Sep 20]. Available from: http://www.cub.org.br/cartilha-cub-m2-amazonas

Câmara Brasileira da Indústria da Construção - CBIC. $\mathrm{CUB} / \mathrm{m}^{2}$. CUB Estadual Acre [online]. Rio Branco: SINDUSCON-AC; 2019a [cited 2019 Mar 14]. Available from: http://www.cub.org.br/cubm2-estadual/AC

Câmara Brasileira da Indústria da Construção - CBIC. INCC/FGV. Índice Nacional da Construção Civil [online]. Belo Horizonte: CBIC-MG; 2019b [cited 2019 Mar 14]. Available from: http://www.cbicdados.com.br/menu/ custo-da-construcao/indice-nacional-de-custos-daconstrucao-inccfgv

Copiello S. Leveraging energy efficiency to finance publicprivate social housing projects. Energy Policy Elsevier 2016; 96: 217-230. http://dx.doi.org/10.1016/j.enpol.2016.06.003.

Deng Y, Chan EHW, Poon SW. Challenge-driven design for public housing: The case of Hong Kong. Frontiers of Architectural Research Elsevier 2016; 5(2): 213-224. http:// dx.doi.org/10.1016/j.foar.2016.05.001.

FinanceOne. Conversor de moedas. 2017 [cited 2017 Jan 18]. Available from: http://financeone.com.br/

Fundação de Tecnologia do Estado do Acre - FUNTAC. Projeto Cidadão Habitar. Rio Branco: FUNTAC; 2003.

Grigoletti G, Sattler MA, Morello A. Analysis of the thermal behavior of a low cost, single-family, more sustainable house in Porto Alegre, Brazil. Energy and Buildings. Elsevier 2008; 40(10): 1961-1971. http://dx.doi.org/10.1016/j. enbuild.2008.05.004

Instituto Brasileiro do Meio Ambiente e dos Recursos Naturais Renováveis - IBAMA; Laboratório de Produtos Florestais - LPF. Edificação do projeto Habitação Popular em Madeira em Pimenta Bueno, RO. Brasília: IBAMA; 2002. Banner. 
Instituto Brasileiro de Geografia e Estatística - IBGE. Geociências 2010 [online]. Rio de Janeiro: IBGE; 2010 [cited 2017 Jan 21]. Available from: http://www.ibge. gov.br/home/geociencias/areaterritorial/principal.shtm Instituto Brasileiro de Geografia e Estatística - IBGE. Estimativa populacional 2015 [online]. Rio de Janeiro: IBGE; 2015 [cited 2016 Oct 27]. Available from: http:// cidades.ibge.gov.br/xtras/perfil.php?codmun $=120040$

Meirelles CRM, Segal ML, Raia F, Mesquita JA, Ferreira HF. O potencial sustentável dos sistemas leves de produção da habitação social. Revista de Arquitetura IMED, 2012, 1(2): 164-173. https://doi.org/10.18256/2318-1109/ arqimed.v1n2p164-173.

Melo JE, Valle IMR, Mello RL, Souza MR. Habitação Popular em Madeira. Brasília: LPF/IBAMA; 2002, p. 100.

Rockwood D, Silva JT, Olsen S, Robertson I, Tran T. Design and prototyping of a FRCC modular and climate responsive affordable housing system for underserved people in the pacific island nations. Journal of Building Engineering. Elsevier 2015; 4: 268-282. http://dx.doi. org/10.1016/j.jobe.2015.09.013.
Serviço Florestal Brasileiro - SFB; Instituto do Homem e Meio Ambiente da Amazônia - IMAZON. A atividade madeireira na Amazônia brasileira: produção, receita e mercados. Belém: MMA; 2010.

Serviço Florestal Brasileiro - SFB; Laboratório de Produtos Florestais - LPF. Proposta técnica de especificações mínimas para casa de madeira do PNHR. Brasília: SFB; 2013. p. 12. Souza LG. Estudo avalia custos de diferentes sistemas de edificação de casas. Revista da Madeira [Internet]. 2013; 137 [cited 2017 Jan 19]. Available from: http://www.remade. com.br/br/ revistadamadeira_materia.php?num=1711

Souza MH, Magliano MM, Camargos JAA, Souza MR. Madeiras tropicais brasileiras. Vol. 1. 2. ed. Brasília: Edições IBAMA; 2002.

Souza MH, Camargos JAA, Teixeira DE, Souza MR. Madeiras tropicais brasileiras. Vol. 2. Brasília: SFB/LPF; 2014.

Wallbaum H, Ostermeyer Y, Salzer C, Zea Escamilla E. Indicator based sustainability assessment tool for affordable housing construction technologies. Ecological Indicators 2012; 18:353-364. http://dx.doi.org/10.1016/j. ecolind.2011.12.005. 